\title{
Assessing Financial Reporting Quality of Listed Companies in Developing Countries: Evidence from Ghana
}

\author{
Joseph Mbawuni ${ }^{1}$ \\ ${ }^{1}$ University of Education, Faculty of Business Education, Winneba, Ghana \\ Correspondence: Joseph Mbawuni, PhD, University of Education, Winneba, Faculty of Business Educaiton, \\ Kumasi- Ghana. Box 1277, Kumasi, Ghana. Tel: 233-243-911-000. E-mail: mbawuni@gmail.com
}

Received: July 23, 2019

Accepted: August 8, 2019

Online Published: August 13, 2019

doi:10.5539/ijef.v11n9p29

URL: https://doi.org/10.5539/ijef.v11n9p29

\begin{abstract}
The adoption of International Financial Reporting Standards (IFRS) in Ghana is expected to improve the quality of financial reporting among companies in Ghana. This paper assesses the extent to which financial reports of companies listed on the Ghana Stock Exchange (GSE) meet financial reporting quality (FRQ) dimensions of IFRS. It was a descriptive study that employed two experienced professional chartered accountants who practice as independent auditors to use FRQ criteria to assess financial reports of 20 purposively selected companies listed on GSE for 2012 and 2013. Given the high inter-rater reliability $(r=.96,95 \%$ C.I., $p<.0001)$, the findings indicate that, overall, FRQ of the listed companies meet FRQ standards by $56.48 \%$. Generally, the financial reports were $60.95 \%$ faithfully represented, $51.01 \%$ relevant, $50.10 \%$ understandable, $40.09 \%$ comparable and $19.75 \%$ timely audited (or $80.25 \%$ untimely). Fundamental FRQ characteristics were more prevalent than enhancing FRQ. Poorly rated FRQ areas were in the use of historical cost as measurement basis, no use of graphs and tables to clarify information, no inclusion of comprehensive glossary, ratios and index, no information on adjustment in past accounting figures for future decisions, and no comparison of current and previous accounting periods and with those of other firms. The study concludes that FRQ of the listed companies is moderate but needs considerable improvement. Implications to theory, practitioners, policy makers and industry regulators are discussed. This study fills the dearth of empirical research in FRQ in IFRS-compliance companies in Sub-Saharan Africa in general and Ghana in particular.
\end{abstract}

Keywords: IFRS adoption, financial reports, accounting, reporting quality, Ghana

\section{Introduction}

The implementation and adoption of the International Financial Reporting Standard (IFRS) by many nations is expected to help standardise international accounting principles and improve financial reporting quality (FRQ) in both developed and developing countries (Owolabi \& Iyoha, 2012; Hail, Leuz, \& Wysocki, 2010; Ramanna \& Sletten, 2014). Stakeholders have the moral, legislative and theoretical mandate evaluate FRQ of companies adopting IFRS to help determine the worth of institutional compliance or conformity to institutional norms of acceptable international accounting behaviour or practice (Ramanna \& Sletten, 2014).

According to the IASB, financial reports should not only present financial position of a company, but also information about the financial performance and changes in financial position of an entity that is useful to a wide range of users in making economic decisions (IASB, 2010). In this regard, there has been much interest in FRQ and many attempts by scholars to operationalise FRQ for the purpose of improving the usefulness of accounting information to various users. To this, The Institute of Chartered Accountants in England and Wales (ICAEW) proposed that information in financial reports should be relevant, accurate, reliable, comparable, understandable, concise, timely, fairly presented and should avoid perverse effects (ICAEW, 2011). The Internal Accounting Standards Board (IASB) in its Exposure Draft (ED) proposed both fundamental quality (relevance, faithful representation) and enhancing quality (understandability, verifiability, comparability and timeliness) aspects of FRQ dimensions (IASB, 2008, 2010), which are being discussed. Without these FRQ dimensions greatly achieved, IFRS-based financial reports may not be useful to users of accounting information (IASB, 2010). This has generated much debate and research in recent times in FRQ dimensions (ICAEW, 2011; Benston, Bromwich, \& Wagenhofer, 2006), FRQ assessment methodologies (Beest et al., 2009; Maines \& Wahlen, 2006; Rezaee, 2003; Willekens, 2008; IASB, 2008, 2010), determinants of FRQ (Kao, \& Wei, 2014) among others from 
scholars and practitioners in developed and developing countries contexts.

In African countries that have adopted IFRS like Ghana, in spite of increasing research in the area of IFRS adoption and its attendant influence on FRQ, empirical research on FRQ of published annual reports of listed companies is very limited. In this regard, there has been research in African countries focusing on IFRS compliance and disclosures (Odia \& Ogiedu, 2013; Zakari, 2014; Aboagye-Otchere \& Agbeibor, 2012; Agyei-Mensah, 2012; Agyei-Mensah, 2013), the influence of firm characteristics and FRQ (Appiah, Awunyo-Vitor, Mireku, \& Ahiagbah, 2016), financial reporting and tax compliance (Abedana, Omane-Antwi \& Oppong, 2016; Amidu, Yorke \& Harvey, 2016), audit and cost of capital (Coffie, Bedi, \& Amidu, 2018), FRQ and audit fees (Musah, Anokye, \& Gakpetor 2018), IFRS and financial reporting in banks and manufacturing firms (Abata, 2015; Okoye \& Nwoye, 2018), financial reporting and economic growth (Temitope, Chibuzo, \& Tolulope, 2019), and FRQ and corporate governance (Uwalomwa, Eluyela, Olubukola, Obarakpo, \& Falola, 2018; Eyenubo, Mohamed, \& Ali, 2017). However, it is surprising that no study as far as the researcher knows has been done to assess the extent to which published financial reports of listed firms truly reflect FRQ dimensions proposed by IFRS and IASB, especially in Ghana. This study hopes to contribute to filling this void in the IFRS and FRQ literature in African countries.

This study will contribute to the IFRS literature by providing the first empirical study on FRQ of published financial reports of listed companies in Ghana after the adoption of IFRS. It will also enhance scholars understanding on the extent to financial reports of listed firms in developing countries reflect FRQ standards of IFRS and IASB. Practically, it will help the Institute of Chartered Accountant, Ghana (ICAG), the statutory regulator of accounting profession and practice in Ghana, by providing new directions for accounting policy evaluation and development in Ghana. Therefore, the main purpose of this paper is to assess the extent to which published financial reports of listed companies on GSE reflect the fundamental and enhancing quality aspects of FRQ after the implementation of IFRS in Ghana.

This study is guided by the following specific objectives:

1). To assess and describe the overall extent to which financial reports of listed firms on GSE reflect FRQ dimensions.

2). To prioritise and describe which fundamental and enhancing quality aspects are more prevalent or lacking in the published financial reports of the listed companies on GSE.

The rest of the paper is organised as follows: section two focuses on a review of literature, section three is the methodology, section four is the results of the study, section five is the implications, and section six is the limitations and conclusion of the study.

\section{Literature Review}

\subsection{FRQ Concept}

FRQ has been defined in terms of its objectives. In this regard, Verdi (2006), defines financial reporting quality as "the precision with which financial reports convey information about the firm's operations, in particular its cash flows, in order to inform equity investors". Tang et al. (2008) define FRQ as "the extent to which the financial statements provide true and fair information about the underlying performance and financial position". The IASB (2010), states that "The objective of financial statements is to provide information about the financial position, performance and changes in financial position of an entity that is useful to a wide range of users in making economic decisions". According to the International Accounting Standards 1 (IAS1) published by the IASB (IASB, 2007, 2010), the primary objective of financial reporting is providing information that is decision-useful. Therefore, quality of FRQ should be defined in terms of its decision-usefulness in line with the standards and recent literature (e.g. Beuselinck \& Manigart, 2007; Jonas \& Blanchet, 2000; McDaniel et al., 2002). In view of this, this study defines FRQ based on the objectives of financial reports stated by the IASB (2010) as a report, "provides information about the financial position, performance and changes in financial position of an entity that is useful to a wide range of users in making economic decisions".

This definition conceptually suggests that FRQ is broader than just the provision of financial information on the position of a firm. It also encompasses other disclosures and non-financial information useful in understanding financial reports and effective decision making. Thus, qualitative characteristics of FRQ help to comprehensively determine the decision usefulness of financial reporting information (IASB, 2008).

Prior literature defines FRQ in terms of the fundamental and enhancing qualitative characteristics underlying decision usefulness as defined in the IAS1 (IASB, 2008; Beest et al., 2009). The fundamental qualitative characteristics are those related to relevance and faithful representation, which are considered as the most 
important because they determine the content of financial reporting information. The enhancing qualitative characteristics are those related to understandability, comparability, verifiability and timeliness, which play a facilitative role to complement the fundamental qualitative characteristics to improve decision usefulness However, they cannot determine financial reporting quality on their own (IASB, 2008).

\section{Relevance}

Relevance is the first fundamental qualitative characteristic of FRQ. According to IASB (2008, p. 35), relevance is referred to as the capability "of making a difference in the decisions made by users in their capacity as capital providers". Relevance captures the predictive and confirmatory value derived from financial reports. "Information about an economic phenomenon has predictive value if it has value as an input to predictive processes used by capital providers to form their own expectations about the future" (IASB, 2008, p. 36). Predictive value focuses on information on the firm's ability to generate future cash flows and shows extensive forward-looking information for user predictions of the firm's future. Confirmatory value of financial report focuses on providing information to users about the past transactions or events that will help them confirm, (Ali, 2008) and decrease the magnitude of users' information risk (Fairchild, 2008) and change users' expectations of the firm. Thus, annual financial reports have confirmatory value "if it confirms or changes past (or present) expectations based on previous evaluations" (IASB, 2008, p. 36).

\section{Faithful Representation}

Faithful representation is the second fundamental qualitative characteristic. According to the IAS1, to faithfully represent economic phenomena that information purports to represent, annual reports must be complete, neutral, and free from material error (IASB, 2008, p. 36). Economic phenomena represented in the annual report are "economic resources and obligations and the transactions and other events and circumstances that change them" (IASB, 2006, p. 48). Faithful representation has been conceptualised and measured using five-related sub-dimensions referring to neutrality, completeness, accuracy or freedom from material error, verifiability and corporate governance (Rezaee, 2003; Maines \& Wahlen, 2006; Willekens, 2008).

Neutrality is "the absence of bias intended to attain a predetermined result or to induce a particular behaviour. Neutral information does not colour the image it communicates to influence behaviour in a particular direction" (IASB, 2008, p. 37). It is about objectivity and balance on the part of the preparer in presenting both positive and negative events. Accuracy, in this regard, narrowly refers to freedom from material error relating to established principles of accounting and finance (Beest et al., 2009; ICAEW, 2011). It also means all principles and assumptions underlying treatment of certain transactions must be well explained and justified in the annual financial report (Beest et al., 2009). Completeness refers to the extent to which the information in annual financial report is comprehensive, covering all relevant areas for useful decision making (ICAEW, 2011). Verifiability is the extent to which the financial report is verifiable by a professional auditor. Since auditing affects FRQ (Coffie et al., 2018; Musah et al., 2018) an unqualified professional auditor's report adds credibility value to financial reporting information by providing reasonable assurance about the degree to which the annual report represents economic phenomena faithfully (Willekens, 2008; Coffie et al., 2018; Musah et al., 2018).

\section{Understandability}

Understandability is the first enhancing qualitative characteristic of FRQ. It means the information should be classified, characterized, and presented clearly and concisely to enable users to comprehend the financial report well (IASB, 2008). Understandability is measured using five items, which are well-organised information (classified and characterized), providing the notes or narrative explanations to the balance sheet and income statement, (Beretta \& Bozzolan, 2004; Iu \& Clowes, 2004) [U2], using tabular or graphic formats to clarifying relationships and ensuring conciseness (IASB, 2006; and using easy words and simple sentences including glossary for unavoidable technical jargon increase ease of users' understanding (Courtis, 2005).

\section{Comparability}

This is a second enhancing qualitative characteristic is comparability. According to IASB, comparability "is the quality of information that enables users to identify similarities in and differences between two sets of economic phenomena" (IASB, 2008, p. 39). In other words, similar situations should be presented the same, while different situations should be presented differently. Thus, comparability includes consistency, which refers to "the use of the same accounting policies and procedures, either from period to period within an entity or in a single period across entities" (IASB, 2008, p. 39). Comparability also includes comparability between different companies (Beuselinck \& Manigart, 2007; Cole et al., 2007; IASB, 2008).

\section{Timeliness}


The final enhancing qualitative characteristic of FRQ defined by IASB is timeliness. According to IASB (2008, p. 40), "Timelines means having information available to decision makers before it loses its capacity to influence decisions" (IASB, 2008, p. 40). It is measured in terms of the amount of days between year-end and the signature on the auditors' report after year end, often using natural logarithm of this amount of days. Information should be provided to users within a timescale suitable for their decision-making purposes (Kaplan, 2012).

\subsection{FRQ Measurement}

There are different methods by which FRQ can be measured, such as accrual models, value relevance models, and comprehensive qualitative characteristics.

Accrual and value relevance model measure FRQ from earnings quality measurement perspective. Earnings quality is defined as "the degree to which reported earnings capture economic reality, in order to appropriately assess a company's financial performance" (Krishnan \& Parsons, 2008). Specifically, accrual models are used to measure the extent of earnings management under current rules and legislation and assumes that managers use discretionary accruals, thereby allowing managers to exert some control to manage earnings (Healy \& Wahlen, 1999; Dechow et al., 1995). It is argued that quality of financial reporting information based on accrual models do not provide direct and comprehensive evidence concerning the quality of financial reporting information and its dimensions of decision usefulness (Beest et al., 2009; Healy \& Wahlen, 1999).

Value relevance models measure the quality of financial reporting information by focusing on the associations between accounting figures and stock-market reactions (e.g. Barth et al., 2001; Choi et al., 1997; Nichols \& Wahlen, 2004). It is assumed that when changes in accounting information correspond to changes in market value of the firm, then earnings information provides relevant and reliable information (Nichols \& Wahlen, 2004). This method is also used to examine earnings persistence, predictive ability, and variability, as elements of earnings quality (Schipper \& Vincent, 2003; Francis et al., 2004). One setback of value relevance models is that the stock market may not be completely efficient. Therefore, stock prices that represent the market value of the firm may not be completely accurate (Nichols \& Wahlen, 2004).

Generally, a major limitation of accrual and value relevance models is that, they focus only on information disclosed in financial statements to assess the FRQ (e.g. Beest et al., 2009; Nichols \& Wahlen, 2004) without including both financial and non-financial information in the complete annual financial report. To have a comprehensive concept of FRQ, it is important for scholars and practitioners to capture both financial and non-financial information as have been argued by past studies (e.g. Beest et al., 2009; Cohen et al., 2004). This study, therefore, adopts a more comprehensive approach to FRQ measurement that includes not only financial position and performance information (relevance and faithful representation which are fundamental), but also to disclosures, and other non-financial information (understandability, comparability and timeliness which are enhancing) that are critically useful for decision making by users. Moreover, this study adopts the empirically validated FRQ measurement tool developed by the Nijmegen Center for Economics (NiCE) to assess FRQ based on the fundamental and enhancing qualitative characteristics of financial reports proposed by IASB (Beest et al., 2009). The NiCE FRQ instrument has five dimensions, namely: relevance and faithful representation, understandability, comparability and timeliness.

\subsection{FRQ After the Adoption of IFRS}

Many researchers maintain that, after the adoption of IFRS, stakeholders have benefited immensely from the quality of accounting information in different ways (Ramanna \& Sletten, 2014). To business organisations, the adoption of IFRS has resulted in greater transparency and understandability, boosted comparability (DeFond, Hu, Hung, \& Li, 2011; Săcărin, Bunea, \& Gîrbină, 2013), has helped fulfill the disclosure requirement for stock exchanges around the world (Daske et al., 2008; Odia \& Ogiedu, 2013; Owolabi \& Iyoha, 2012; Ramanna \& Sletten, 2014). To investors, the adoption of IFRS has resulted in higher quality information for investors for investment decisions (Barth, Landsman, \& Lang, 2008; Florou \& Pope, 2012), more confidence in the information presented, more timely financial reports, easier access to financial reporting, among others (Ahmed \& Duellman, 2011; Ball, 2006; Barth et al., 2008; Mbawuni, 2018).

In the developing country context, and in African in particular several studies have been done relating IFRS and FRQ in different countries. For example, Abata (2015) examined the impact of international financial reporting standards (IFRS) adoption on financial reporting practice in The Nigerian Banking Sector. Using data from the annual reports of fourteen Nigerian listed banks, the findings indicated that the quantitative differences in the financial reports prepared under NGAAP and IAS/IFRS are statistically significant. The study therefore concludes that IFRS have impacted on financial reporting in the Nigerian Banking sector. 
Eyenubo et al. (2017) analysed whether audit committee size matters in the financial reporting quality of the quoted firms in Nigeria. Using a sample of 189 companies and 6-year observation from the period of 2011-2015, their findings indicated that corporate governance recommendation as a mean of strengthening the monitoring and oversight role of audit committee plays an importance role in the financial reporting process.

Okoye and Nwoye (2018) examined IFRS compliance appraisal in selected Nigerian and Ghanaian manufacturing companies. Using dataset financial statements of a sample of 44 manufacturing companies (22 companies each in Nigeria and Ghana) listed on the floors of the Nigerian and Ghana Stock Exchanges for the years 2007-2011 (Ghana) and 2012-2016 (Nigeria) respectively, the findings showed that a significant difference existed in the compliance quality of post-IFRS financial statements prepared by public listed manufacturing companies in Nigeria and Ghana, with Nigeria having better IFRS disclosures compliance edge over Ghana. This implies that the regulatory approach to IFRS implementation in both countries apparently differs. The study however recommends that a more robust regulatory oversight on companies' full compliance to IFRS disclosure requirements be upheld towards achieving a commendable level of comparison in both countries' IFRS Financial Statements as expected. More so, companies' consistent full compliance to IFRS requirements should hence be adopted as one of the perquisites for her continued listing by the Nigerian and Ghana Stock Exchanges.

Uwalomwa et al. (2018) studied corporate governance and quality of financial statements: a study of listed Nigerian banks for the period 2008-2015. The study found that board size had a non-significant negative relationship with the timeliness of financial reports. Also, the study observed that board independence also had a non-significant negative relationship with the timeliness of financial reports. Finally, it was observed that foreign executives on the board had a significant positive relationship with the timeliness of financial reports. The study thus recommended that the existing legal framework in Nigeria should be developed that clearly specifies the rights and obligations of a bank, its management and, of course, other stakeholders.

\subsection{Adoption IFRS in Ghana}

IFRS was adopted in Ghana on 1 January 2007. This was to replace its out-dated Ghana National Accounting standards (GNAS). By this adoption all listed companies, public entities, banks, and insurance companies are mandated to comply with IFRS to guide them in their accounting operations, practices and annual financial reporting. The adoption of IFRS has attracted much research attention in Ghana. The following section reviews some research conducted in the area of FRQ and its relation to IFRS in Ghana.

Aboagye-Otchere and Agbeibor (2012) studied the suitability of IFRS for Small and Medium-sized Entities (IFRS for SMES) or small businesses in Ghana. Among other things, they found that small businesses also did not receive requests to provide such information. In total, 19 of the 27 issues addressed by IFRS and assessed in the study were found to be irrelevant to small businesses in Ghana. Amoako and Asante (2012) studied the extent of compliance of listed banks in Ghana with IFRS, with particular reference to financial instruments IFRS 7. They found that comparatively, all the listed banks improved upon their IFRS 7 required compliance level, scoring $98 \%$ to $100 \%$ average compliance level for both 2008 and 2009. They claim that what might have accounted for this trend was that the management and staff of the Ghanaian banks are now getting more familiar with the IFRS in 2009 than in 2008 and that has reflected in the improved performance with the IFRS 7 disclosure requirement.

Moreover, Agyei-Mensah (2012) investigated the extent of disclosure by firms complying with IAS 1. The key relationships examined are the relationship between level of disclosure and company size, profitability, liquidity, leverage and auditor size. The results showed that the disclosure level, mean of $60.9 \%$, indicate that most of the firms listed on the Ghana Stock Exchange did not overwhelmingly comply with the IAS 1 disclosure requirements. The result showed that only liquidity was associated with the extent of disclosure. The results did not provide support for a positive relationship between company size, profitability, leverage and auditor size.

Furthermore, Agyei-Mensah (2013) also investigated the quality of financial reports before and after adopting IFRSs in Ghana, and also the influence of firm-specific characteristics which include firm size, profitability, debt equity ratio, liquidity and audit firm size on the quality of financial information disclosed by firms listed on the Ghana Stock Exchange. The researcher was conducted through detailed analysis of financial statements for the pre-official adoption period (2006) and post adoption period (2008) of the listed firms. Through regression analysis, the results of the quality of financial information disclosure mean of $76.80 \%$ (pre adoption) and $87.09 \%$ (post adoption) for the two years indicate that the quality of financial reports has improved significantly after adopting IFRSs. The findings confirmed that the implementation of IFRSs generally reinforce accounting disclosure quality. It also indicated overwhelming compliance of listed firms with the IFRS framework. 
Yiadom and Atsunyo (2014) examined compliance with IFRS by 31 listed companies in Ghana using their 2010 financial statements. They found an overall mean compliance of $85.8 \%$ in Ghana. The study further examined relationships between company attributes and the extent of compliance. They also found that company attributes such as size, profitability, auditor type, internationality and industry type were associated positively with IFRSs compliance.

Abedana et al. (2016) studied how the adoption of IFRS / IAS in Ghana has impacted on the quality of corporate financial reporting and related corporate tax burden. Using a disclosure index approach correlation analysis for financial report of a sample 22 firms listed on the GSE before and after adoption of IFRS, the authors reported that a significant positive correlation existed between the disclosure quality (based on the qualitative characteristics of relevance, understandability, comparability and faithful presentation) of listed firms following the adoption of IFRSs. They concluded that the quality of disclosure based on IAS 12 improved significantly following the adoption of IFRSs.

Appiah et al. (2016) researched into the association between five firm-specific characteristics and the level of compliance with International Financial Reporting Standards (IFRS) by companies listed on Ghana Stock Exchange. Drawing data on firm size, profitability, leverage, auditor type and firm age of 31 listed firms from 2008 to 2012, their study found a positive significant relationship between the level of compliance and firm size, auditor type, cross-listing and sector (information and communications technology (ICT) and agro-forestry). On the contrary, the level of compliance exhibits a negative significant association with leverage and firm age. It is observed that the level of compliance is not related to profitability. However, their study did not examine the effect of mandatory IFRS adoption on financial analysts' information environment in the sub-Saharan Africa context.

Amidu et al. (2016) examined the effects of financial reporting standards on tax avoidance and earnings quality in Ghana. Using dataset froma sample of 119 firms after the implementation of IFRS, the finding indicated that IFRS adoption reduced the incidence of tax avoidance as the level of earnings quality increases when firms use internal funding to increase their profitability levels. They also found that the relatively high-quality earnings and low incidence of tax avoidance among firms in Ghana is attributed to the adoption of IFRS and the interaction of firm size to equity capital and the strategy of firms in Ghana to finance their operations with debt.

Musah et al. (2018) examined the effects of IFRS adoption and the Big 4 audit firms on audit and non-audit fees in Ghana. Using a sample of financial and non-financial firms in Ghana, the results showed that IFRS adoption has a positive and significant relationship with audit and non-audit fees post IFRS adoption. The results further revealed that there is positive association between the year of IFRS adoption (transition period) and audit and non-audit fees. On the Big 4 audit firms, the results show that the Big 4 charge higher audit and non-audit fees than non-big 4 as there was a positive and significant relationship between Big 4 and audit and non-audit fees. The results supported the argument that the adoption of IFRS increased the complexities of financial reporting and audit risk resulting in a higher audit and non-audit fees charged during the transition period and post IFRS adoption.

\subsection{The Main Research Gap}

Despite the significant attempt by researchers to understand IFRS adoption and FRQ, there is scanty empirical research that specifically assesses the extent to which the annual financial statements of listed companies reflect the fundamental and enhancing qualitative characteristics proposed by IASB for IFRS adopters. This study finds empirical relevance by contributing to filling this void in the FRQ research in Ghana.

\subsection{Conceptual Framework}

Based on the literature reviewed, a conceptual framework was developed for this study (Figure 1). It depicts the dimensions of FRQ measurement framework proposed by IASB (IASB, 2008, 2010) for all adopters of IFRS including Ghana and operationalised by Beest et al. (2009) to be used in future studies and applied by Yurisandi and Puspitasari (2015). The main dimensions of the FRQ framework are relevance, faithful representation (neutrality, completeness, accuracy or freedom from material error, verifiability and corporate governance), which are fundamental qualitative characteristics of FRQ. It also includes understandability and comparability and timeliness which are enhancing qualitative characteristics of FRQ (Beest et al., 2009; Maines \& Wahlen, 2006; Rezaee, 2003; Willekens, 2008; IASB, 2008, 2010). 


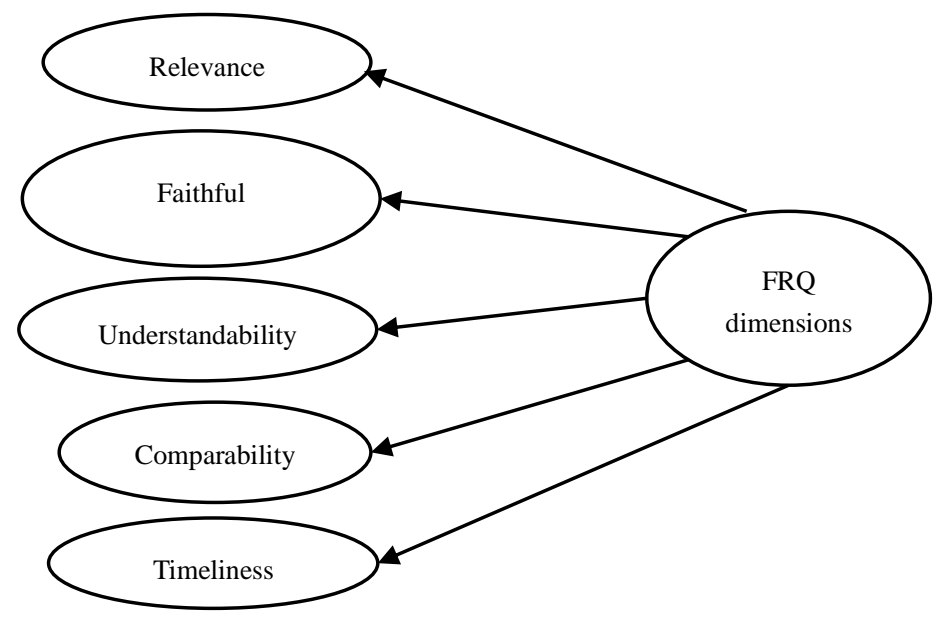

Figure 1. Conceptual framework

\section{Methodology}

\subsection{Rationale for Choice of Context}

This research was conducted in Ghana for two important reasons because Ghana's adoption of IFRS has increased stakeholders' interest on how IFRS has translated into FRQ among Ghanaian firms. Second, Ghana's emerging economy offers great investment opportunities to international investors who expect financial reports to meet international professional standards. For these reasons, it is interesting to research the extent to which annual financial reports of listed firms in GSE meet FRQ standards of IFRS and IASB.

\subsection{Research Design, Population and Sampling}

This study used an in-depth descriptive case study design that sought to use secondary data of listed companies on GSE available on the GSE website. The population for the study comprised 37 listed companies out of which 20 were purposively selected. The sample selection was informed by two factors: the published financial report must be available on the GSE website and for 2012 and 2013 financial years. 2012 and 2013 years were chosen because it was for those years most of the listed companies had published their financial reports.

\subsection{Development of Research Instrument/Measures}

This study adopted the empirically validated FRQ measurement tool developed by the Nijmegen Center for Economics (NiCE) to assess FRQ based on the fundamental and enhancing qualitative characteristics of financial reports proposed by IASB (Beest et al., 2009). Consequently, a self-administered, structured questionnaire was developed (see Table 1). It consisted of five dimensions, namely, relevance and faithful representation, understandability, comparability and timeliness. Each of the dimensions of FRQ had different numbers of measurement items that formed or reflected the construct it represents: Relevance had 4; Understandability and Faithful Representation had 5 each; Comparability had 6 and Timeliness had 1 measurement item. These summed up to 21 measurement items in all. (see Table 1). The FRQ dimensions were measured using a five-point scale, coded 1 to 5 respectively, that reflected the magnitude of the FRQ dimension being measured as developed by Beest et al. (2009).

\subsection{Administration of Research Instrument}

Two experienced professionally chartered accountants who have over 20 years each in practice as independent auditors were selected to evaluate the extent to which each of the 20 companies' financial reports for 2012 and 2013 meet the FRQ standard on the 21-item questionnaire. The use of experts as judges in rating individuals or entities on specific attributes related to the experts' field of discipline is highly recommended in qualitative research paradigm (Marshall \& Rosmann, 2006). To ensure high reliability of the responses, the two experts' ratings should show high inter-rater reliability above 0.70 for the results to be acceptable as recommended in previous research (Saunders, Lewis, \& Thornhill, 2012). As recommended by researchers for in-depth qualitative analysis, the two experts were purposively selected because they had over twenty years of professional auditing experience and had been auditing financial reports of many companies in Ghana. This was to ensure that they were capable of providing the right judgement after reading and analyzing the financial reports of the selected 
companies one after the other to judge whether they meet the FRQ standards.

\subsection{Data Analysis Methods}

Data were analysed using descriptive analysis involving means, percentages to describe the most prevalent and lacking FRQ dimension items, and make comparison between the dimensions. A bivariate correlation was used to assess inter-rater agreement level between the two experts who judged the financial reports using the FRQ questionnaire as criteria. Thus, inter-rater reliability was assessed using correlation of the mean ratings rater 1 and rater 2 for each of the 21 FRQ dimension for each year (2012 and 2013). This was because the focus was on the measurement item level, not comparing company by company. The methods for this study's descriptive analysis are explained below:

- Descriptors for means of FRQ items. All FRQ item means are approximated to one decimal place (e.g, 4.23 is considered 4.2 and 4.35 is 4.4). Ratings below mean of 2.5 is described as poor because it falls below the average standard. A mean between 2.5 and 2.99 is average, 3.0 to 3.99 is good, 4.0 to 4.99 is very good and 5.0 is excellent.

- Descriptors for percentages of FRQ. Percentage FRQ score of 0 to 39.99 is very poor, 40 to 49.99 is poor, 50 to 59.99 is average, 60 to 69.99 is good, 70 to 79.99 very good, 80 to 89.99 excellent, and 90 to 100 is outstanding.

- Calculating Combined Raters' Mean Score (CRMS). Add the means for the two raters for each item for each year and divide it into two (e.g. mean for R1 by Rater 1 plus mean for R1 by rater 2, divide the answer by two).

- Calculating Expected Dimension Total Score (EDTS). EDTS is the total numerical score for each dimension. Since each item was assigned five-point scale or five responses, each item has 5 numerical points, the total responses for each item in each dimension sums up to get EDTS for each FRQ dimension. Thus, for Relevance dimension, there are 4 items, each with 5 points, totally 20 points for the construct. Following this procedure, Faithful representation and Understandability will each have EDTS of 25 points. Comparability will have 28 points because it has 6 items, each has 5 points except C3 which has only 3 items. Timeliness has one item for 5 points.

- Calculating Percentage Dimension Score (PDS). PDS measures the extent to which the actual FRQ rating for each company's financial report reflect the expected FRQ standard set. It is estimated by dividing the total mean ratings (TMR) for a dimension by the EDTS and multiply it by $100 \%$ (i.e., TMR/ EDTS $\mathrm{x}$ $100 \%$ ). The TMR for a dimension is estimated by adding mean ratings for all items in a dimension. For example, TMR for Relevance is 10.05 and EDTS for Relevance is 20, therefore, PDS for Relevance is $10.05 / 20 * 100=50.25 \%$.

\section{Results of Study}

Tables 1 and 2 have the same headings, presenting results for 2012 and 2013 respectively. They indicate results of the raters' assessment of FRQ of the listed companies. Both Tables 1 and 2 show the mean ratings for each FRQ dimension items and standard deviations of the means for Rater 1 and 2 separately. They also show the combined mean ratings of the two raters shown as joint raters' mean or combined raters' mean Score (CRMS) and percentage dimension score (PDS) in percentages for each FRQ dimension (in bold and italised). Finally, the Tables show summary statistics such as inter-rater reliability or correlation (r), overall FRQ for 2012 and 2013 by Rater 1 and Rater 2, and the mean of the overall FRQ by the two raters.

\subsection{Reliability of Research Instrument}

The Pearson correlation(r) was run to determine the level of agreement between two qualified auditor's judgement. The result in Table 1 shows that there was high agreement between the two experts' judgements for $2012, r=.96(95 \% \mathrm{CI}), \mathrm{p}<.0001$, and for $2013, \mathrm{r}=.96(95 \% \mathrm{CI}), \mathrm{p}<.0001$. Given good inter-rater reliability of the data, we proceed to examine the results for each research objective.

\subsection{Overall FRQ of the Sampled Financial Reports}

Tables 1 shows that the overall FRQ for the listed companies for 2012 is $56.91 \%$ and 56.06 by Rater 1 and Rater 2 respectively. The mean overall FRQ from the two Raters indicated 2.53 representing $56.48 \%$. Using our intuitive descriptors (see section 3.5 of this study), it indicates average or moderate FRQ. Similarly, Table 2 shows that the overall FRQ for the listed companies for 2013 is $57.12 \%$ and 55.82 by Rater 1 and Rater 2 respectively. The mean overall FRQ from the two raters indicated mean of 2.52 representing $56.47 \%$ similar to 56.48 for the 2012 accounting year. Using our intuitive descriptors, the $56.47 \%$ also indicates average FRQ. 
Table 1. FRQ rating for listed firms for 2013 accounting year

\begin{tabular}{|c|c|c|c|c|c|c|}
\hline FRQ dimensions & $\begin{array}{c}\text { Rater } 1 \\
\text { Mean }\end{array}$ & SD & $\begin{array}{c}\text { Rater } 2 \\
\text { Mean }\end{array}$ & SD & $\begin{array}{r}\text { Joint Raters' } \\
\text { Mean* }\end{array}$ & Remarks \\
\hline $\begin{array}{l}\text { R1 } \text { Forward-looking information } \\
\text { R2 } \text { information for business }\end{array}$ & 2.40 & 0.68 & 3.00 & 0.00 & 2.70 & Apart subsection \\
\hline $\begin{array}{l}\text { opportunities/risk } \\
\text { R3 uses fair value as measurement }\end{array}$ & 3.30 & 0.66 & 3.15 & 0.37 & 3.23 & Provide useful non-financial information \\
\hline basis & 1.55 & 0.51 & 1.00 & 0.00 & 1.28 & Mostly Historical cost are used \\
\hline $\mathrm{R} 4$ feedback information on & $\begin{array}{l}2.80 \\
2.51\end{array}$ & 0.62 & $\begin{array}{l}3.15 \\
2.58\end{array}$ & 0.37 & $\begin{array}{l}2.98 \\
2.54\end{array}$ & Feedback is present \\
\hline PDS for relevance (\%) & $50.2 \%$ & & $51.5 \%$ & & $50.88 \%$ & Average or moderate \\
\hline U1 It is well organized & 3.55 & 0.60 & 3.80 & 0.41 & 3.68 & $\begin{array}{l}\text { Order of components are clearly presented } \\
\text { Report has explanations that describes what }\end{array}$ \\
\hline $\mathrm{U} 2$ clear notes to the balance sheet & 3.30 & 0.73 & 3.25 & 0.64 & 3.28 & happens \\
\hline U3 use of Graphs and tables & 1.00 & 0.00 & 1.00 & 0.00 & 1.00 & No graphs are presented in annual reports \\
\hline U4 The language is easy & 3.40 & 0.99 & 3.65 & 0.49 & 3.53 & Not much jargon \\
\hline U5 Has comprehensive glossary & $\begin{array}{l}1.00 \\
2.45\end{array}$ & 0.00 & $\begin{array}{l}1.00 \\
2.54\end{array}$ & 0.00 & $\begin{array}{l}1.00 \\
2.50\end{array}$ & No glossary is in report \\
\hline PDS for Understandability & $49 \%$ & & $50.80 \%$ & & $49.90 \%$ & Poor \\
\hline $\begin{array}{l}\text { F1 It explains the assumptions ... } \\
\text { F2 It explains choice of accounting }\end{array}$ & 2.20 & 0.62 & 2.65 & 0.88 & 2.43 & General explanation \\
\hline principles & 2.45 & 0.83 & 2.55 & 0.83 & 2.50 & Explained why \\
\hline $\begin{array}{l}\text { F3 highlights the positive and negative } \\
\text { events }\end{array}$ & 2.70 & 0.66 & 2.75 & 0.44 & 2.73 & Emphasised positive and negative events \\
\hline F4 has auditor's report & 5.00 & 0.32 & 5.00 & 0.00 & 5.00 & $\begin{array}{l}\text { Unqualified opinion, financial figures plus } \\
\text { controls }\end{array}$ \\
\hline $\begin{array}{l}\text { F5 It discloses corporate governance } \\
\text { issues }\end{array}$ & $\begin{array}{l}2.70 \\
3.01\end{array}$ & 0.73 & $\begin{array}{l}2.60 \\
3.11\end{array}$ & 0.50 & $\begin{array}{l}2.65 \\
3.06\end{array}$ & $\begin{array}{l}\text { Apart subsection for corporate governance } \\
\text { information }\end{array}$ \\
\hline PDS for Faithful Repres.(\%) & $60.2 \%$ & & $62.20 \%$ & & $61.20 \%$ & Good \\
\hline C1 The notes to changes...explain.. & 2.45 & 0.76 & 2.50 & 0.76 & 2.48 & Minimum explanation \\
\hline $\mathrm{C} 2$ The notes to revisions & 2.90 & 0.97 & 3.00 & 0.65 & 2.95 & No revision /clear notes \\
\hline $\begin{array}{l}\text { C3 info on previous accounting } \\
\text { period's figures }\end{array}$ & 1.25 & 0.44 & 1.05 & 0.22 & 1.15 & $\begin{array}{l}\text { No adjustments in previous accounting years } \\
\text { figures }\end{array}$ \\
\hline $\begin{array}{l}\mathrm{C} 4 \text { The results are compared with } \\
\text { previous }\end{array}$ & 1.95 & 0.22 & 2.15 & 0.49 & 2.05 & $\begin{array}{l}\text { Information compared with only the previous } \\
\text { year }\end{array}$ \\
\hline $\begin{array}{l}\text { C5 Information is comparable to other } \\
\text { firms' }\end{array}$ & 1.15 & 0.37 & 1.10 & 0.31 & 1.13 & Judgement based on accounting policies \\
\hline C6 It presents financial index numbers & & & & & & \\
\hline and ratios & $\begin{array}{l}1.25 \\
1.83\end{array}$ & 0.44 & $\begin{array}{l}1.90 \\
1.95\end{array}$ & 0.55 & $\begin{array}{l}1.58 \\
1.89\end{array}$ & 1 to 2 ratios \\
\hline PDS for Comparability.(\%) & $39.1 \%$ & & $41.79 \%$ & & $40.45 \%$ & Very poor \\
\hline $\begin{array}{l}\mathrm{T} 1 \text { days the auditor signs the auditors' } \\
\text { report }\end{array}$ & 4.30 & 1.42 & 3.70 & 0.92 & 4.00 & \\
\hline PDS for Timeliness & $\begin{array}{c}\mathbf{8 6} \% \\
(14 \%)\end{array}$ & & $74.00 \%$ & & $80 \%$ & $\begin{array}{l}\text { Very poor, because } 80 \% \text { untimely is } 20 \% \\
\text { timely }\end{array}$ \\
\hline Summary statistics for 2012 & & & & & & \\
\hline Inter-rater Correlation (r) & 0.96 & & & & & High inter-rater reliability or agreement \\
\hline$\%$ of FRQ for 2012 by Rater & 56.91 & & 56.06 & & & Good \\
\hline Overall \% for FRQ for 2012 & 56.48 & & & & 2.53 & Good \\
\hline
\end{tabular}

Source: Field data, 2019 Notes: scale: 1- strongly disagree, .. 5 - strongly agree, percentage dimension score (PDS), *same as Combined Raters' Mean Score (CRMS), $\mathrm{n}=20$ firms 
Table 2. FRQ rating for listed firms for 2013 accounting year

\begin{tabular}{|c|c|c|c|c|c|c|}
\hline FRQ dimensions & $\begin{array}{c}\text { Rater } 1 \\
\text { Mean }\end{array}$ & SD & $\begin{array}{l}\text { Rater } 2 \\
\text { Mean }\end{array}$ & SD & $\begin{array}{c}\text { Joint Raters' } \\
\text { Mean** }\end{array}$ & Remarks \\
\hline R1 Forward-looking information & 2.40 & 0.68 & 3.00 & 0.00 & 2.70 & Apart subsection \\
\hline \multicolumn{7}{|l|}{$\mathrm{R} 2$ information for business } \\
\hline opportunities/risk & 3.45 & 0.69 & 3.15 & 0.37 & 3.30 & Provide useful non-financial information \\
\hline $\mathrm{R} 3$ uses fair value as measurement basis & 1.55 & 0.51 & 1.00 & 0.00 & 1.28 & Only Historical cost are used \\
\hline \multirow[t]{2}{*}{ R4 feedback information on } & 2.85 & 0.67 & 3.05 & 0.22 & 2.95 & Feedback is present \\
\hline & 2.56 & & 2.55 & & 2.56 & \\
\hline PDS for relevance $(\%)$ & $51.25 \%$ & & $51.00 \%$ & & $51.13 \%$ & Average or moderate \\
\hline U1 It is well organized & 3.60 & 0.60 & 3.90 & 0.31 & 3.75 & Order of components are clearly presented \\
\hline U2 clear notes to the balance sheet & 3.40 & 0.68 & 3.20 & 0.52 & 3.30 & Report has very short descriptions \\
\hline U3 use of Graphs and tables & 1.00 & 0.00 & 1.00 & 0.00 & 1.00 & No graphs are presented in annual reports \\
\hline U4 The language is easy & 3.35 & 0.93 & 3.65 & 0.49 & 3.50 & Not much jargon \\
\hline \multirow[t]{2}{*}{ U5 Has comprehensive glossary } & 1.05 & 0.22 & 1.00 & 0.00 & 1.03 & No glossary is in report \\
\hline & 2.48 & & 2.48 & & 2.52 & \\
\hline PDS for Understandability & $49.60 \%$ & & $51.00 \%$ & & $50.30 \%$ & Average or moderate \\
\hline F1 It explains the assumptions ... & 2.20 & 0.52 & 2.65 & 0.88 & 2.43 & General explanation \\
\hline $\begin{array}{l}\text { F2 It explains choice of accounting } \\
\text { principles }\end{array}$ & 2.55 & 0.94 & 2.65 & 0.93 & 2.60 & Explained why \\
\hline $\begin{array}{l}\text { F3 highlights the positive and negative } \\
\text { events }\end{array}$ & 2.55 & 0.51 & 2.65 & 0.59 & 2.60 & Emphasised on positive and negative events \\
\hline F4 It has an unqualified auditor's report & 4.90 & 0.31 & 5.00 & 0.00 & 4.95 & $\begin{array}{l}\text { Unqualified opinion, financial figures plus } \\
\text { controls }\end{array}$ \\
\hline \multirow[t]{2}{*}{ F5 It discloses corporate governance issues } & 2.60 & 0.88 & 2.60 & 0.60 & 2.60 & section for corporate governance information \\
\hline & 2.96 & & 2.96 & & 3.04 & \\
\hline PDS for Faithful Repres.(\%) & $59.20 \%$ & & $62.20 \%$ & & $60.70 \%$ & Good \\
\hline $\mathrm{C} 1 \mathrm{The}$ notes to changes...explain.. & 2.35 & 0.67 & 2.45 & 0.83 & 2.40 & Minimum explanation \\
\hline $\mathrm{C} 2$ The notes to revisions & 2.75 & 0.97 & 2.95 & 0.69 & 2.85 & No revision /clear notes \\
\hline C3 info on previous accounting period's & & & & & & No adjustments in previous accounting years \\
\hline figures & 1.15 & 0.37 & 1.00 & 0.00 & 1.08 & figures \\
\hline $\begin{array}{l}\text { C4 The results are compared with previous } \\
\text { C5 Information is comparable to other }\end{array}$ & 2.00 & 0.00 & 2.00 & 0.00 & 2.00 & $\begin{array}{l}\text { Information compared with only the previous } \\
\text { year }\end{array}$ \\
\hline $\begin{array}{l}\text { C5 Information is comparable to other } \\
\text { firms' }\end{array}$ & 1.25 & 0.55 & 1.15 & 0.37 & 1.20 & Judgement based on accounting policies \\
\hline \multicolumn{7}{|l|}{ C6 It presents financial index numbers and } \\
\hline ratios & $\begin{array}{l}1.30 \\
1.80\end{array}$ & 0.47 & $\begin{array}{l}1.90 \\
1.80\end{array}$ & 0.64 & $\begin{array}{l}1.60 \\
1.85\end{array}$ & 1 to 2 ratios \\
\hline PDS for Comparability.(\%) & $38.57 \%$ & & $40.89 \%$ & & $39.73 \%$ & Very poor \\
\hline $\mathrm{T} 1$ days the auditor signs the auditors' report & 4.35 & 1.23 & 3.70 & 0.80 & 4.03 & \\
\hline PDS for Timeliness & 87.00 & & $74.00 \%$ & & 80.50 & $\begin{array}{l}\text { Very poor, because } 80 \% \text { untimely is } 20 \% \\
\text { timely }\end{array}$ \\
\hline \multicolumn{7}{|l|}{ Summary statistics for 2013} \\
\hline Inter-rater Correlation (r) & 0.96 & & & & & High inter-rater reliability or agreement \\
\hline$\%$ of FRQ for 2012 by Rater & 57.12 & & 55.82 & & & Average or moderate \\
\hline Overall \% for FRQ for 2012 & 56.47 & & & & 2.52 & Average or moderate \\
\hline
\end{tabular}

Source: Field data, 2019. Notes: scale: 1 - strongly disagree, ... 5 - strongly agree, percentage dimension score (PDS), ** same as Combined Raters' Mean Score (CRMS), $\mathrm{n}=20$ firms.

\subsection{Assessment of FRQ Dimensions of the Financial Reports}

Table 1 shows that, for 2012, the total mean score for relevance dimension was 2.5 and 2.58 for Raters 1 and 2 respectively with a combined raters' mean score (CRMS) of 2.54 representing a percentage dimension score (PDS) of $50.2 \%$ (Rater 1) $51.5 \%$ (Rater 2) and average of 50.88\%. Thus, the financial reports are $50.88 \%$ relevant in FRQ, which is described as average or moderate. Following the same analysis procedure, the mean PDS in Table 1 showed that the financial reports reflected $49.90 \%$ Understandability, $61.20 \%$ Faithful representation, $40.45 \%$ Comparability and $20 \%$ Timeliness or $80 \%$ Untimeliness.

Table 2 shows that, for 2013 accounting year, the total mean score for relevance dimension was 2.56 and 2.55 for 
Raters 1 and 2 respectively with a combined raters' mean score (CRMS) of 2.56 representing a percentage dimension score (PDS) of $51.25 \%$ (Rater 1) $51 \%$ (Rater 2) to get an average of $51.13 \%$. Thus, the financial reports are $51.13 \%$ relevant in FRQ, which is described as average or moderate. Following the same analysis procedure, the mean PDS in Table 2 showed that the financial reports reflected 50.30\% Understandability, 60.70\% Faithful Representation, $39.73 \%$ Comparability and $19.50 \%$ Timely or $80.50 \%$ Untimely audited).

While there is no significant difference between the raters' assessment for 2013 and 2013, and for each of the FRQ dimensions, the results for understandability in 2012 was $49.90 \%$ described as very poor but in 2013 it was $50.30 \%$, which was average. This implies a slight improvement, though not really statistically significant ( $\mathrm{p}>$ 0.05). Thus, Relevance dimension of the reports was rated good for both 2012 and 2013, understandability of the reports was rated poor for 2012 but average for 2013, faithful representation of the reports was rated very good for 2012 and 2013, comparability of the reports was rated very poor for both 2012 and 2013, and timeliness of the reports was rated very poor for both years.

Within the context of fundamental and enhancing qualitative dimensions of FRQ, the results indicated that, on average, FRQ dimension that the financial reports of the listed companies was reflected most was Faithful Representation $(60.95 \%)$, followed by Relevance (51.01\%), Undersstandability (50.10\%), Comparability $(40.09 \%)$ and the least rated was Timeliness (19.75 timely or $80.25 \%$ untimely). Thus, the financial reports reflected more of Faithful representation and Relevance dimensions which belong to the fundamental qualitative characteristics of FRQ than they captured Understanding, Comparability and Timeliness. In fact, the poorly rated FRQ dimension of the reports were Comparability and Timeliness that are enhancing qualitative characteristics.

Within each FRQ dimension, the results in Tables 1 and 2 show that for both 2012 and 2013 accounting years, the following items received considerably low mean ratings below 2.5, indicating unacceptable or poor FRQ:

1) R3 Mostly Historical cost are used

2) U3 No graphs are presented in annual reports

3) U5 No glossary is in annual report

4) F1 Only general explanation

5) $\mathrm{C} 1$ The notes to changes in the balance sheet are minimum explanation

6) C3 No information on adjustments in previous accounting period's figures.

7) C4 Information in report is compared with only the previous year

8) C5 Information is comparable to other firms. Judgement based on accounting policies

9) C6 It presents little financial index numbers and ratios, just 1 to 2 ratios.

Conversely, the following items received considerably high mean ratings, indicating acceptable or good FRQ:

1) Reports included unqualified opinion, financial figures plus internal controls

2) General explanation

3) Explained why

4) Emphasised on positive events, negative events are mentioned

5) Apart subsection for corporate governance information

6) No revision /clear notes

7) It takes longer days for the annual reports to be audited.

\section{Discussion of Findings}

The overarching purpose of this study was to assess the extent to which published financial reports of listed companies on GSE reflect the fundamental and enhancing quality aspects of FRQ after the implementation of IFRS in Ghana. This section discusses the findings of the study to address the study's objectives.

\subsection{Overall FRQ of Financial Reports of Listed Firms on GSE}

This study found that the mean overall FRQ for the listed companies was 2.53 representing $56.475 \%$ (56.48\% for 2012 and $56.47 \%$ for 2013), which is described as moderate or average. This implies that the FRQ of financial reports of the selected listed companies in Ghana reflected 56.48\% of the FRQ standards set by the IASB through the instrumentation of the IFRS adoption by Ghana. These findings are similar to those of Tasios and Bekiaris (2012) who found that auditors perceive overall FRQ of Greek companies to be moderate (average 
value of 3.13).

This further shows a positive evidence that Ghanaian listed companies are making efforts to fully operationalise the FRQ requirement the adoption of IFRS intends to achieve in accounting and financial practices of adopted countries. This FRQ performance of the listed firms on GSE accentuates the theory of adoption of innovation in the context of accounting innovations driven by the implementation of IFRS (Rogers, 2003). According to the theory of innovation, early adoption often comes with few adopters and within early adopters, adjustments and adaption to new innovations tend to be gradual more than fast. With 56\% of FRQ, the listed companies confirm that they are gradually but significantly making positive efforts to achieving greater level in FRQ. One reason that may account for this moderate performance is the effective monitoring work of the ICAG and the authorities of the GSE to ensure that listed companies are operating on business practices and meeting quality industry and professional accounting standards.

\subsection{Extent of Fundamental and Enhancing Quality in the Financial Reports}

First, the study found that, the financial reports reflected more of Faithful Representation and Relevance dimensions which belong to the fundamental qualitative characteristics of FRQ than they captured Understanding, Comparability and Timeliness. In fact, the poorly rated FRQ dimension of the reports were Comparability and Timeliness that are enhancing qualitative characteristics. Since fundamental qualitative characteristics are deemed more important than enhancing characteristics (IASB, 2010, Beest et al., 2009), the Ghanaian companies listed on the GSE have conformed to IFRS and not deviated from placing greater emphasis on fundamental FRQ than enhancing FRQ as expected of IFRS compliant-firms. The findings that FRQ of Ghanaian listed companies were high for Faithful Representation and Relevance lend support to similar findings in past studies (e.g., Beest et al., 2009; Tasios \& Bekiaris, 2012).

Second, this study found that, Comparability and Timelines of the financial reports received poor ratings. According to the results, Comparability problems included the fact that the financial reports had minimum explanation to explain notes to changes in the balance sheet, had no information on adjustments in previous accounting period's figures, had information in report that compared with only the previous year, but not comparable to other firms, made judgement based on accounting policies, and presented little financial index numbers and ratios, just 1 to 2 ratios.

Third, this study found that Timeliness of the financial reports was the least and the worst rated FRQ dimension. This implies that it took relatively longer time for the financial reports to be submitted for auditing and signing after the accounting year ended. This finding is similar to those in past studies (e.g., Puasa, Salleh, \& Ahmad, 2014; Yurisandi \& Puspitasari, 2015), who found that many companies adopting IFRS took longer time to submit their financial report for auditing. Yaacob and Che-Ahmad (2012) found that in Malaysia, after the FRS 138 adoption, it took firms longer time to issue audit report, thereby increasing audit delay and affecting FRQ.

Fourth, the findings showed, though Faithful Representation, Relevance, Understandability generally received good ratings, some specific areas of these dimensions were poorly rated. Specifically, the financial reports provided general explanations and not extensive and specific information required for decision usefulness. The reports also used mostly historical cost and not fair values as expected. Surprisingly, the reports had no graphics and no glossary to explain information in annual reports.

\section{Implications of Findings}

This study has theoretical, practical and policy implications for improving FRQ in Ghanaian companies.

\subsection{Theoretical Implications}

First, theoretically, this study makes an important contribution to the FRQ literature by providing one of the first empirical study on the extent to which FRQ of annual reports of companies meet FRQ standards of IASB in developing countries in general, and Ghana in particular. It especially provides empirical findings indicating that, financial reports of listed companies in GSE reflect FRQ standards by $56.48 \%$, which could be described as moderate performance under the supervision of ICAG and regulators of GSE.

Second, for scholars interested in FRQ research, this study has confirmed gradual adoption and integration process proposed in the innovation diffusion theory (Rogers, 2003) and endogenous innovation growth theory (Uzawa, 1965) applied to IFRS adoption (Temitope et al., 2019; Kim, Liu, \& Zheng, 2012). Companies adopting IFRS do not fully comply to IFRS and FRQ standards because they might be constrained to employ local or previously familiar accounting principles instead of those proposed by IFRS. This study showed that companies used only or mostly historical cost instead of fair value as basis for measurement as proposed by the IFRS for its FRQ standard. In China, Kim et al. (2012) posited that the adoption process had been gradual for fair value, a 
concept not allowed in Chinese accounting prior to their adoption of IFRS. Thus, full IFRS adoption is gradual for some companies (De George, Li, \& Shivakumar, 2016).

Third, this study finds theoretical evidence that companies adopting FRQ standards of IFRS give priority to the fundamental qualitative characteristics over the enhancing qualitative characteristics to demonstrate commitment to fundamental issues in accounting standards (IASB, 2010; Beest et al., 2009; Yurisandi \& Puspitasari, 2015) as is the case of listed companies in Ghana. This study showed that the financial reports were considerably relevant and faithfully represented. All the reports included unqualified auditors' reports which strengthened their faithful representation. Thus, the evidence shows that, despite the improvements that are still needed in FRQ of developing countries adopting IFRS, the companies are able to maintain a positive balance expected of them by giving priority to fundamental quality aspects of their annual financial reports. Third, this study has confirmed many previous studies that delays in timeliness of FRQ is one of the greatest FRQ challenge of companies adopting IFRS both in developed and developing countries (Yaacob \& Che-Ahmad, 2012; Puasa et al., 2014; Yurisandi \& Puspitasari, 2015). Fifth, this study provides new theoretical insight into areas of short-falls in FRQ in developing countries. The evidence showed that even in the most fundamental qualitative characteristics of FRQ received good ratings, the financial reports did not include comprehensive glossary, ratios, index, and graphic and tabular formats to clarify information for useful decisions.

\subsection{Practical Implications}

To management of companies listed on the GSE, the study has shown that despite their good effort take to achieve good accounting reporting standards, there is still more room for improvement. Specifically, management need to improve upon the FRQ of their annual financial reports by adopting fair value as measurement basis to improve the relevance of the annual reports. They should also include comprehensive glossary, ratios, index, graphical and tabular displays to clarify information, include information on adjustment in past accounting figures for future decisions, and endeavor to make useful comparison of the current and previous accounting periods with the company and with those of other firms. Moreover, since auditing quality affects FRQ (Coffie et al., 2018; Musah et al., 2018), management should work harder to ensure that their financial reports are audited early enough to avoid long delays in auditing of the financial reports and to improve upon the timeliness quality of the reports for useful stakeholder decisions (Puasa et al., 2014).

To Policy makers and regulatory bodies in Ghana, the findings imply that they are making achieving some considerable success in monitoring listed companies to deliver good FRQ. However, the results also imply that they have to intensify monitoring and enforcement mechanisms to achieve better FRQ than has been portrayed in this study. There is also the need to increase education and research on FRQ to stakeholders, especially, preparers and accounting students to better understand the technicalities in financial reporting and how increase its usefulness to decision makers. One area for accounting education and training as revealed in this study notable of mention is the use of fair value as measurement basis in financial reporting. In the words of Mbawuni (2017, p. 111), "The complexity that comes with the use of fair value, which is IFRS 13, as bases for measurement in financial reporting has attracted a lot of attention by scholars and practitioners, as measurement base is another important challenge, especially in financial reporting. Therefore, more education and training emphasis in this area will enhance accountants' expertise in overcoming the challenges that come with fair value."

\section{Conclusions and Limitations}

In conclusion, this study has attempted to provide an initial evidence of the extent to which annual financial reports of listed companies in Ghana reflect FRQ standards set by IASB/IFRS using a purposively selected sample of 20 firms listed on the GSE. This study found that FRQ of the listed firms was moderate but still needs improvement in both the fundamental and enhancing qualitative characteristics of FRQ proposed by IASB. The main limitation of this study is that it is focused on the context of Ghana and used only 20 financial reports of listed firms for 2012 and 2013. Future research should use more current data (2014 to 2018) and include non-listed firms and compare the results with those of this study. In addition, future research should apply the FRQ dimensions adopted in this study but seek the views of a wider sample of professional accountant on the FRQ of annual reports to enhance our understanding of FRQ after IFRS adoption in Ghana and other developing countries.

\section{References}

Abata, M. A. (2015). The impact of international financial reporting standards (IFRS) adoption on financial reporting practice in the Nigerian banking sector. Journal of Policy and Development Studies, 289(1850), $1-16$. 
Abedana, V., Omane-Antwi, K., \& Oppong, M. (2016). Adoption of IFRS/IAS in Ghana: Impact on the quality of corporate financial reporting and related corporate tax burden. Research Journal of Finance and Accounting, $7(8), 10-25$.

Aboagye-Otchere, F., \& Agbeibor, J. (2012). The International Financial Reporting Standard for Small and Medium-sized Entities (IFRS for SMES) Suitability for small businesses in Ghana. Journal of Financial Reporting and Accounting, 10(2), 190-214. https://doi.org/10.1108/19852511211273723

Agyei-Mensah, B. K. (2012). Association between firm-specific characteristics and the levels of disclosure of financial information of rural banks in the Ashanti Region of Ghana. Journal of Applied Finance \& Banking, 2(1), 69-92. https://doi.org/10.2139/ssrn.1840423

Agyei-Mensah, B. K. (2013). Adoption of International Financial Reporting Standards (IFRS) in Ghana and the Quality of Financial Statement Disclosures. International Journal of Accounting and Financial Reporting, 3, 269-286. https://doi.org/10.5296/ijafr.v3i2.4489

Ahmed, A. S., \& Duellman, S. (2011). Evidence on the role of accounting conservatism in monitoring managers' investment decisions. Accounting \& Finance, 51(3), 609-633. https://doi.org/10.1111/j.1467-629X.2010.00369.x

Ajibade, A. T., Okeke, O. C., \& Olurin, O. T. (2019). International Financial Reporting Standard (IFRS) Adoption and Economic Growth: A Study of Nigeria and Kenya. South Asian Journal of Social Studies and Economics, 3(3), 1-8. https://doi.org/10.9734/sajsse/2019/v3i330108

Amidu, M., Yorke, M. S., \& Harvey, S. (2016). The effects of financial reporting standards on tax avoidance and earnings quality: a case of an emerging economy. Journal of Accounting and Finance, 16(4), 639-659.

Amoako, G. K., \& Asante, S. (2012). Compliance with International Financial Reporting Standard 7 (IFRS 7): A Study of Listed Banks in Ghana. Research Journal of Finance and Accounting, 3(4), 66-73.

Appiah, K. O., Awunyo-Vitor, D., Mireku, K., \& Christian, A. (2016). Compliance with international financial reporting standards: The case of listed firms in Ghana. Journal of Financial Reporting and Accounting, 14(1), 131-156. https://doi.org/10.1108/JFRA-01-2015-0003

Ball, R. (2006). International Financial Reporting Standards (IFRS): Pros and cons for investors. Accounting and business research, 36(sup1), 5-27. https://doi.org/10.1080/00014788.2006.9730040

Barth, M. E., Landsman, W. R., \& Lang, M. H. (2008). International accounting standards and accounting quality. Journal of Accounting Research, 46(3), 467-498. https://doi.org/10.1111/j.1475-679X.2008.00287.x

Barth, M., Beaver, W., \& Landsman, W. (2001). The relevance of the value relevance literature for financial accounting standard setting: another view. Journal of Accounting and Economics, 31, 77-104. https://doi.org/10.1016/S0165-4101(01)00019-2

Beest, F. V., Braam, G. J. M., \& Boelens, S. (2009). Quality of Financial Reporting: Measuring qualitative characteristics. Working Paper, NiCE.

Benston, G. J., Bromwich, M., \& Wagenhofer, A. (2006). Principles-versus rules-based accounting standards: the FASB's standard setting strategy. Abacus, 42(2), 165-188. https://doi.org/10.1111/j.1467-6281.2006.00196.x

Beretta, S., \& Bozzolan, S. (2004). A framework for the analysis of firm risk communication. The International Journal of Accounting, 39(3), 265-288. https://doi.org/10.1016/j.intacc.2004.06.006

Beuselinck, C., \& Manigart, S. (2007). Financial reporting quality in private equity backed companies: The impact of ownership concentration. Small Business Economics, 29(3), 261-274. https://doi.org/10.1007/s11187-006-9022-1

Choi, B., Collins, D. W., \& Johnson, W. B. (1997). Valuation Implications of Reliability Differences: The Case of Nonpension Postretirement Obligations, The Accounting Review 72(3), 351-383.

Coffie, W., Bedi, I., \& Amidu, M. (2018). The effects of audit quality on the costs of capital of firms in Ghana. Journal of Financial Reporting and Accounting, 16(4), 639-659. https://doi.org/10.1108/JFRA-03-2017-0018

Cohen, J., Krishnamorthy, G. \& Wright, A. (2004). The corporate governance mosaic and financial reporting quality. Journal of Accounting Literature, 23, 87-152.

Courtis, J. (2005). Readability of annual reports: Western versus Asian evidence. Accounting, Auditing, and Accountability Journal, 8(2), 4-17. https://doi.org/10.1108/09513579510086795 
Daske, H., Hail, L., Leuz, C., \& Verdi, R. (2008). Mandatory IFRS reporting around the world: Early evidence on the economic consequences. Journal of Accounting Research, 46(5), 1085-1142. https://doi.org/10.1111/j.1475-679X.2008.00306.x

De George, E., Xi, L., \& Shivakumar, L. (2016) A review of the IFRS adoption literature. Review of Accounting Studies, 21(3). 898-1004. https://doi.org/10.1007/s11142-016-9363-1

Dechow, P. M., Sloan, R. G., \& Sweeny, A. P. (1995). Detecting earnings management. The Accounting Review, 70(2), 193-225.

Dechow, P., \& Dichev, I. (2002). The Quality of Accruals and Earnings: The Role of Accrual Estimation Errors. The Accounting Review, 77, 35-59. https://doi.org/10.2308/accr.2002.77.s-1.35

DeFond, M. L., Hung, M., Li, S., \& Li, Y. (2015). Does mandatory IFRS adoption affect crash risk? The Accounting Review, 90(1), 265-299. https://doi.org/10.2308/accr-50859

DeFond, M., Hu, X., Hung, M., \& Li, S. (2011). The impact of mandatory IFRS adoption on foreign mutual fund ownership: The role of comparability. Journal of accounting and economics, 51(3), 240-258. https://doi.org/10.1016/j.jacceco.2011.02.001

Eyenubo, S. A., Mohamed, M., \& Ali, M. (2017). An Empirical Analysis on the Financial Reporting Quality of the Quoted Firms in Nigeria: Does Audit Committee Size Matter?. International Journal of Academic Research in Business and Social Sciences, 7(9), 50-63. https://doi.org/10.6007/IJARBSS/v7-i9/3308

Florou, A., \& Pope, P. F. (2012). Mandatory IFRS adoption and institutional investment decisions. The Accounting Review, 87(6), 1993-2025. https://doi.org/10.2308/accr-50225

Francis, J., LaFond, R., Olsson, P., \& Schipper, K. (2004). Cost of Equity and Earnings Attributes. The Accounting Review, 79(4), 967-1010. https://doi.org/10.2308/accr.2004.79.4.967

Hail, L., Leuz, C., \& Wysocki, P. (2010). Global accounting convergence and the potential adoption of IFRS by the US (Part I): Conceptual underpinnings and economic analysis. Accounting Horizons, 24(3), 355-394. https://doi.org/10.2308/acch.2010.24.3.355

Healy, P., \& Wahlen, J. (1999). A review of the earnings managment literature and its implications for standard settings. Accounting Horizons, 13(4), 365-383. https://doi.org/10.2308/acch.1999.13.4.365

IASB (2008). Exposure Draft on an improved Conceptual Framework for Financial Reporting: The Objective of Financial Reporting and Qualitative Characteristics of Decision-useful Financial Reporting Information. London.

International Accounting Standard Board. (2010). The Conceptual Framework for Financial Reporting, issued in September 2010. In: South African Institute of Chartered Accountants (Ed.), SAICA members' handbook (2010 ed., Vol. 2A). Pietermaritzburg: LexisNexis

Iu, J., \& Clowes, C. (2004). Evaluating a measure of content quality for accounting narratives (with an empirical application to narratives from Australia, Hong Kong, and the United States). In Proceedings of Fourth Asia Pacific Interdisciplinary Research in Accounting Conference APIRA 2004 (pp. 1-21). Nanyang Technological Univeristy, Nanyang Business School.

Iyoha, F. O., \& Owolabi, A. (2012). Adopting international financial reporting standards (IFRS) in Africa: Benefits, prospects and challenges. African J. Accounting, Auditing and Finance, 1(1), 77-86. https://doi.org/10.1504/AJAAF.2012.046127

Jonas, G. J., \& Blanchet, J. (2000). Assessing quality of financial reporting. Accounting horizons, 14(3), 353-363. https://doi.org/10.2308/acch.2000.14.3.353

Kaplan Financial Knowledge Bank. (2012). The qualitative characteristics of financial information. Kaplan Publishing.

Kao, T. H. W. H. S. (2014). The effect of IFRS, information asymmetry and corporate governance on the quality of accounting information. Asian Economic and Financial Review, 4(2), 226.

Kim, J. B., Liu, X., \& Zheng, L. (2012). The impact of mandatory IFRS adoption on audit fees: Theory and evidence. The Accounting Review, 87(6), 2061-2094. https://doi.org/10.2308/accr-50223

Krishnan, G. V., \& Parsons, L. M. (2008). Getting to the Bottom Line: An exploration of Gender and Earnings Quality. Journal of Business Ethics, 78, 65-76. https://doi.org/10.1007/s10551-006-9314-z

Maines, L. A., \& Wahlen, J. M. (2006). The nature of accounting information reliability: Inferences from archival 
$\begin{array}{llll}\text { and } & \text { experimental } & \text { research. } & \text { Accounting }\end{array}$ https://doi.org/10.2308/acch.2006.20.4.399

Marshall, C., \& Rosmann, G. B. (2006). Designing qualitative research (4th ed.). Thousand Oaks, California: Sage.

Mbawuni, J. (2018). Perceived Benefits and Challenges of IFRS Adoption in Ghana: Views of Members of Institute of Chartered Accountants, Ghana (ICAG). International Journal of Financial Research, 9(1), 99-114. https://doi.org/10.5430/ijfr.v9n1p99

McDaniel, L., Martin, R. D., \& Maines, L. A. (2002). Evaluating financial reporting quality: The effects of financial expertise vs. financial literacy. (s-1), 139-167. https://doi.org/10.2308/accr.2002.77.s-1.139

Musah, A., Anokye, F. K., \& Gakpetor, E. D. (2018). The effects of IFRS adoption and Big 4 audit firms on audit and non-audit fees: Evidence from Ghana. Accounting and Management Information Systems, 17(3), 330-352. https://doi.org/10.24818/jamis.2018.03002

Nichols, D., \& Wahlen, J. (2004). How Do Earnings Numbers Relate to Stock Returns? A Review of Classic Accounting Research with Updated Evidence. Accounting Horizons, 18(4), 263-286. https://doi.org/10.2308/acch.2004.18.4.263

Odia, J. O., \& Ogiedu, K. O. (2013). IFRS adoption: Issues, challenges and lessons for Nigeria and other adopters. Mediterranean Journal of Social Sciences, 4(3), 389. https://doi.org/10.5901/mjss.2013.v4n3p389

Okoye, E. I., \& Nwoye, U. J. (2018). IFRS Compliance Appraisal: Evidence from Nigeria and Ghana. Academic Journal of Economic Studies, 4(4), 19-27.

Owolabi, A., \& Iyoha, F. O. (2012). Adopting International Financial Reporting Standards (IFRS) in Africa: benefits, prospects and challenges. African Journal of Accounting, Auditing and Finance, 1(1), 77-86. https://doi.org/10.1504/AJAAF.2012.046127

Puasa, S., Salleh M. F. M., \& Ahmad A. (2014). Audit Committee and Timeliness of Financial Reporting: Malaysian Public Listed Companies. Middle-East Journal of Scientific Research, 22(2), 162-175.

Ramanna, K., \& Sletten, E. (2014). Network effects in countries' adoption of IFRS. The Accounting Review, 89(4), 1517-1543. https://doi.org/10.2308/accr-50717

Rezaee, Z., Smith, L. M., \& Szendi, J. Z. (2010) 'Convergence in accounting standards: Insights from academicians and practitioners. Advances In Accounting, 26(1), 142-154. https://doi.org/10.1016/j.adiac.2010.01.001

Rogers, E. M. (2003). Diffusion of Innovations (5th ed.). New York, NY: The Free Press.

Săcărin1, M., Bunea, Ş., \& Gîrbină, M. M. (2013). Perceptions of accounting Professionals on IFRS application at The individual financial statements: Evidence from Romania. Accounting and Management Information Systems, 12(3), 405-423.

Saunders, M., Lewis, P., \& Thornhill, A. (2012). Research Methods for Business Students (6th ed.). Pearson.

Schipper, K., \& Vincent, L. (2003). Earnings Quality, Accounting Horizons, 17, 97-110. https://doi.org/10.2308/acch.2003.17.s-1.97

Sharinah, P., Mohd, F. M., \& Azlina, A. (2014). Audit committee and timeliness of financial reporting: Malaysian public listed companies. Middle-East Journal of Scientific Research, 22(2), 162-175.

Tang, Q, Chen, H., \& Zhijun, L. (2008). Financial reporting quality and investor protection: A global investigation. Working Paper. https://doi.org/10.2139/ssrn.1290910

Tasios, S., \& Bekiaris, M. (2012). Auditor's perceptions of financial reporting quality: The case of Greece. International Journal of Accounting and Financial Reporting, 2(1), 57-74. https://doi.org/10.5296/ijafr.v2i1.1286

Uwalomwa, U., Eluyela, D. F., Olubukola, R. U., Obarakpo, T., \& Falola, I. (2018). Corporate governance and quality of financial statements: A study of listed Nigerian banks. Banks and Bank System, 13(3), 12-23. https://doi.org/10.21511/bbs.13(3).2018.02

Uzawa, H. (1965). Optimum Technical Change in an Aggregative Model of Economic Growth (PDF). International Economic Review, 6(1), 18-31. https://doi.org/10.2307/2525621

Verdi, R. S. (2006). Financial reporting quality and investment efficiency. https://doi.org/10.2139/ssrn.930922 
Yaacob, N. M., \& Che-Ahmad, A. (2012). Adoption of FRS 138 and Audit Delay in Malaysia. International Journal of Economics and Finance, 4(1), 167-176. https://doi.org/10.5539/ijef.v4n1p167

Yiadom, E. M., \& Atsunyo, W. (2014). Compliance with International Financial Reporting Standards by Listed Companies in Ghana. International Journal of Business and Management, 9(10), 87-100. https://doi.org/10.5539/ijbm.v9n10p87

Yurisandi, T., \& Puspitasari, E. (2015). FRQ Before and After IFRS Adoption using NiCE qualitative characteristics measurement. Procedia Social and Behavioural Sciences, 211(2015) 644-652. https://doi.org/10.1016/j.sbspro.2015.11.091

Zakari, M. A. (2014). Challenges of International Financial Reporting Standards (IFRS) Adoption in Libya. International Journal of Accounting and Financial Reporting, 4(2), 390-412. https://doi.org/10.5296/ijafr.v4i2.6302

\section{Copyrights}

Copyright for this article is retained by the author(s), with first publication rights granted to the journal.

This is an open-access article distributed under the terms and conditions of the Creative Commons Attribution license (http://creativecommons.org/licenses/by/4.0/). 